\title{
Pengaruh Manajemen Aset Terhadap Tingkat Optimalitas Aset Tetap (Tanah) Pemerintah Provinsi Jambi
}

\author{
Wawan Devis Wahyu \\ Fakultas Ekonomi dan Bisnis Islam IAIN Kerinci, w2nwahyu@gmail.com
}

\author{
DOI \\ https://doi.org/10.26740/jupe.v10n1.p45- \\ $\underline{56}$
}

\author{
Article history \\ Received \\ 6 December 2021 \\ Revised \\ 9 December 2021 \\ Accepted \\ 12 December 2021
}

\section{How to cite \\ Wahyu, D.W. (2022). Pengaruh Manajemen Aset Terhadap Tingkat Optimalitas Aset Tetap (Tanah) Pemerintah Provinsi Jambi. Jurnal Pendidikan Ekonomi (JUPE), 10(1), 45- 56. \\ https://doi.org/10.26740/jupe.v10n1.p45- $\underline{56}$}

Kata Kunci: inventarisasi, legal audit, penilaian, pengawasan \& pengendalian aset, optimalisasi aset tetap tanah.

Keywords: inventory, legal audit, valuation, supervision and control of assets, optimization of land fixed assets.

\section{Corresponding author}

Wawan Devis Wahyu

w2nwahyu@gmail.com

\begin{abstract}
Abstrak
Tujuan penelitian ini adalah untuk menganalisis pengaruh manajemen aset tetap (tanah) milik Pemprov Jambi. Sebanyak 46 responden sampel yang diambil dalam penelitian ini dengan menggunakan metode purposive sampling. Inventarisasi aset, legal audit aset, penilaian aset, serta pengawasan dan pengendalian aset merupakan varibel-variabel yang digunakan pada penelitian ini. Dari hasil analisis yang memanfaatkan alat uji Regresi Linear Berganda memperlihatkan hasil secara uji individual bahwa terbukti inventarisasi aset berpengaruh positif dan signifikan terhadap optimalitas aset tetap (tanah) yang artinya cocok dengan hipotesis, akan tetapi secara individual legal audit penilaian asset, serta pengawasan dan pengendalian aset tidak terbukti berpengaruh positif dan signifikan terhadap tingkat optimalitas aset tetap (tanah) yang artinya tidak sesuai dengan hipotesis, Sedangkan hasil secara simultan memperlihatkan keempat variabel tersebut yaitu inventarisasi aset, legal audit aset, penilaian aset, serta pengawasan dan pengendalian aset terbukti berpengaruh signifikan dan positif terhadap tingkat optimalitas aset tetap (tanah), hasil tersebut dibuktikan dengan nilai F-hitung > F-tabel.
\end{abstract}

\begin{abstract}
The purpose of this study was to analyze the effect of fixed asset management (land) belonging to the Jambi Provincial Government. A total of 46 sample respondents were taken in this study using purposive sampling method. Asset inventory, asset legal audit, asset valuation, and asset monitoring and control are the variables used in this study. From the results of the analysis using the Multiple Linear Regression test tool, it shows the results of an individual test that it is proven that asset inventory has a positive and significant effect on the optimality of fixed assets (land) which means that it matches the hypothesis, but individually legal audits of asset valuation, as well as asset monitoring and control not proven to have a positive and significant effect on the level of optimality of fixed assets (land) which means that it is not in accordance with the hypothesis, while the results simultaneously show that the four variables, namely asset inventory, asset legal audit, asset valuation, and asset monitoring and control, have a significant and positive effect. to the optimal level of fixed assets (land), the results are proven by the value of $F$-count $>F$-table.
\end{abstract}




\section{PENDAHULUAN}

Pemerintah daerah yang dikelola negara dapat membuat jenis pendapatan dengan meningkatkan pengelolaan sumber daya pemerintah lingkungan dengan menemukan cara yang penting untuk memajukan sumber daya pemerintah lingkungan yang saat ini diurutkan belum ideal dan menilai kegagalan sumber daya tidak aktif memiliki tempat dengan legislatif terdekat yang membutuhkan biaya fungsional dan dukungan yang luar biasa. Salah satu persoalan mendasar dalam pengawasan barang (sumber daya) provinsi adalah campur aduk dalam administrasi informasi produk (sumber daya). Hal ini membuat legislatif lingkungan berpikir bahwa sulit untuk mengetahui tanpa diragukan lagi sumber daya yang mereka kendalikan/hasilkan, sehingga sumber daya yang diawasi oleh pemerintah negara bagian terdekat seringkali tidak digunakan secara ideal. Menurut (Siregar, 2004) ada beberapa fase sumber daya yang mungkin dimiliki dewan untuk membangun sumber daya yang dimiliki, khususnya stok sumber daya, tinjauan hukum, penilaian sumber daya, dan pengecekan dan pengendalian sumber daya. Dimana dengan asumsi empat fase sumber daya para eksekutif diselesaikan dengan tepat, itu akan memberikan keuntungan luar biasa bagi otoritas publik, terutama administrasi negara tetangga dalam memperluas kemampuan, kecukupan, dan membuat nilai tambah dalam mengawasi sumber daya dengan cara yang efisien, bertanggung jawab, dan langsung.

Kemampuan dalam pengelolaan keuangan besar pengaruhnya pada perkembangan daerah tersebut. Dengan meningkatkan pengelolaan sumber daya pemerintah daerah, dapat menghasilkan suatu jenis pendapatan, khususnya dengan menemukan cara-cara penting untuk memajukan sumber daya pemerintah lingkungan yang saat ini dianggap belum ideal dan menilai kegagalan sumber daya yang tidak aktif dan menyebabkan kerusakan fungsional yang sangat besar. dan biaya pendukung. Dengan kekuatan yang diberikan kepada pemerintah terdekat, ia harus memiliki opsi untuk memperkuat kelimpahan ruang yang diklaim, misalnya melalui pengelolaan aset. Memahami sumber daya secara keseluruhan adalah sesuatu yang memiliki harga diri. Sesuai dengan buku Standar Penilai Indonesia (SPI, 2007), sumber daya dapat dicirikan sebagai aset yang umumnya diklaim atau berpotensi dibatasi oleh substansi bisnis atau pemerintah dan keuntungan finansial dan tambahan ramah masa depan dapat diperoleh, dan dapat diperkirakan sebagai sejauh unit kas.

Persoalan mendasar dalam penatausahaan barang dagangan (sumber daya) teritorial adalah campur aduk dalam penatausahaan informasi produk (sumber daya). Hasil ini di negara-negara tetangga mengalami masalah mengetahui dengan pasti sumber daya yang mereka awasi atau kendalikan, sehingga pengelolaan sumber daya pemerintah terdekat cenderung tidak ideal dalam penggunaannya. Sesuai Siregar (Siregar, 2004) untuk memperluas sumber daya yang diklaim ada beberapa fase sumber daya dewan yang harus dimungkinkan, termasuk stok sumber daya, tinjauan yang sah, penilaian sumber daya, pengamatan dan kontrol sumber daya. Keempat fase sumber daya ini, bila dilakukan dengan tepat, akan memberikan keuntungan yang luar biasa bagi otoritas publik, khususnya legislatif lingkungan, dalam meningkatkan kecukupan, kecakapan, dan membuat para eksekutif lebih menghargai sumber daya yang tepat, lugas, dan bertanggung jawab.

Dengan wilayah yang tergolong cukup luas, Pemda Provinsi Jambi harus mampu mengelola aset-aset yang sesuai sesuai dengan PP No. 6 Tahun 2006 yaitu tentang pengelolaan barang milik negara / daerah sudah diubah dengan PP No. 27 tahun 2014 (Hartanto, 2019) sehingga bisa dipertanggungjawabkan pada pemerintah pusat, yaitu aset tetap (fixed asset) berupa tanah. Tetapi pada prakteknya Provinsi Jambi belum bisa mengelola aktiva secara baik, hal terlihat oleh hasil finalcial statment Pemda Provinsi Jambi hingga tahun 2017 telah menyandang predikat Wajar Tanpa Pengecualian (WTP) dengan paragrap penjelasan. Salah satu penjelasannya adalah tentang pengelolaan barang milik daerah (BMD) yang masih belum efektif. Menurut (Akbar \& Lukman, 2010) konsep manajemen aset pertama kali diturunkan oleh bisnis swasta. Pemanfaatan ide sumber daya dewan telah ditampilkan untuk memberikan hasil positif dan keuntungan besar bagi organisasi wilayah swasta. Administrasi wilayah privat ini mulai terlihat oleh otoritas pemerintah dan organisasi publik. Sejalan dengan itu, gagasan tentang sumber daya para eksekutif dikenal sebagai metode yang bisa digunakan oleh otoritas publik dalam menangani sumber dayanya.

Salah satu permasalahan yang muncul adalah karena Pemerintah Provinsi Jambi belum bisa memaksimalkan aset tetap (tanah) yang dimiliki Pemprov Jambi (RUSTAM et al., 2021). Hal ini bisa terlihat ada beberapa masalah utama inventarisasi aset yang hingga saat ini belum terdapat databaku terkait jumlah luas tanah milik P emprov Jambi,termasuk juga masalah legal audit. Hingga tahun 2014 tercatat Pemerintah Provinsi Jambi memiliki sebanyak 292 bidang tanah. Dari jumlah tersebut yang baru besertifikat sebanyak 135 bidang (46,23 persen), 77 bidang (26,37 persen) belum memiliki sertifikat, dan sisanya 80 bidang $(27,40) \quad$ sedang dalam proses pengurusan di BPN. Sejumlah bidang tanah yang dimiliki oleh Pemerintah Provinsi Jambi tersebut ternyata juga belum diketahui berapa nilainya. Beberapa masalah aktiva menjadi kendala Provinsi Jambi agar bisa mendapatkan opini WTP tanpa paragrap penjelasan. Seperti yang 
ditunjukkan oleh Siregar (2004:519) peningkatan sumber daya adalah siklus kerja sumber daya para eksekutif yang bertujuan untuk memajukan potensi aktual, area, harga, jumlah/volume, moneter dan tanggung jawab yang sah atas sumber daya.

Dalam Penelitian sebelumnya, banyak yang telah mengeksplorasi dampak sumber daya yang adil dan kuadrat dari optimalitas aset tetap. (Ouertani et al., 2008), dalam eksplorasinya mengusulkan cara untuk menangani administrator sumber daya yang membantu untuk mendorong data sumber daya yang sukses teknik papan. Data tentang pola keberadaan sumber daya yang muncul pada tahap pengadaan, pengaturan, penggunaan, pemeliharaan dan penghapusan pada umumnya sulit didapat dan umumnya data ini hilang, sehingga diperlukan data sumber daya yang terkoordinasi dalam sistem dewan (Phelps, 2009), melihat hubungan antara pemikiran, praktik dan hasil dalam sumber daya para eksekutif untuk memahami unsur-unsur kemajuan dari properti dewan ke sumber daya para eksekutif yang terjadi di Inggris dan Rusia. Sebuah sistem berwawasan diciptakan untuk mengukur mengapa asosiasi mencoba sumber daya dewan; apa yang mereka lakukan dan capai. Secara keseluruhan, sumber daya eksekutif di Inggris lebih berkembang dan terkendali daripada Rusia, ini karena mediasi pemerintah pusat dan penyertaan dinamis sumber daya aktor dewan. (Akbar \& Lukman, 2010), Sumber daya eksekutif adalah Metodologi yang pada mulanya diterapkan oleh pihak swasta dan telah terbukti memberikan keuntungan yang sangat besar, sehingga mulai dianut oleh otoritas publik untuk mengawasi sumber daya publik. Eksekusi sumber daya dewan di area publik lebih banyak dalam kerangka administrasi, misalnya organisasi jalan (jalan), jalur kereta api (rembesan), saluran (kursus), organisasi kekuasaan (power), dan mulai tumbuh. untuk sumber daya properti asli. seperti tanah dan bangunan. Salah satu sumber daya penting kota adalah pusat rekreasi. Taman merupakan salah satu komponen Ruang Terbuka Hijau (RTH) memiliki manfaat serta peran yang luar biasa bagi jaringan metropolitan. Akan tetapi, sebagian besar kegunaan taman terletak pada penataan jarak jauh dan tidak langsung memberikan keuntungan finansial yang besar seperti pusat perbelanjaan, pembayaran, toko, dan kantor sosial lainnya. Oleh karena itu, keberadaan pusat rekreasi secara teratur dilarang. Masalah pembibitan yang berbeda yang diidentifikasikan dengan jumlah dan kualitas sering ditemukan di komunitas perkotaan yang sangat besar di Indonesia, salah satunya adalah Bandung. Dalam mengatasi masalah ini, memarkir dewan harus dimungkinkan dengan menerapkan ide sumber daya para eksekutif. Tinjauan ini mengharapkan untuk menerapkan sumber daya cara eksekutif untuk menangani pusat rekreasi yang bergantung pada Kerangka Data Geografis (GIS) untuk merampingkan kapasitas pusat rekreasi. Tinjauan ini menggunakan pendekatan ekspresif melalui pembicaraan dengan prosedur dengan pihak-pihak yang terkait dengan dewan taman dan persepsi lapangan di taman-taman di wilayah pemeriksaan. Dengan demikian, sumber daya dewan adalah metodologi yang mengambil bagian penting dalam periode pelaksanaan persiapan tata ruang (penggunaan dan kontrol). Penerapannya telah terbukti bermanfaat bagi pengelolaan sumber daya publik seperti pondasi jalan, limbah, tanah, bangunan, dan sebagainya. (Hanis et al., 2011), memimpin penelitian untuk mengetahui kesulitan yang dihadapi negara-negara tetangga Indonesia saat merangkul sumber daya publik sistem eksekutif. Rencana/prosedur/pendekatan. Analisis kontekstual di otoritas publik Daerah Sulawesi Selatan digunakan sebagai cara untuk menangani pencapaian tujuan pemeriksaan. Penyelidikan kontekstual ini mencakup dua prosedur pengumpulan informasi rapat dan pemeriksaan arsip. Penemuan Konsekuensi dari tinjauan tersebut menunjukkan bahwa ada kesulitan kritis yang perlu diawasi oleh pemerintah Indonesia di dekatnya sambil merangkul sumber daya publik dalam struktur eksekutif. Kesulitan-kesulitan ini: kekurangan sistem kelembagaan dan legitimasi untuk membantu penggunaan sumber daya dewan, aturan sumber daya publik yang tidak menguntungkan, berbagai lingkungan yang terlibat dengan sumber daya publik, interaksi eksekutif, kerumitan tujuan pemerintah lingkungan, non-aksesibilitas informasi untuk mengawasi properti publik, dan membatasi SDM. Batasan/Saran Penelitian Tinjauan ini dibatasi pada satu analisis kontekstual. Ini adalah penyelidikan awal dari laporan yang lebih besar menggunakan berbagai analisis kontekstual. Eksplorasi dasar juga meneliti peluang bagi legislatif di sekitar untuk merangkul dan menjalankan sumber daya terbuka dewan. Inventiveness/esteem Penemuan-penemuan makalah memberikan kontribusi yang berharga bagi para pembuat strategi, akademisi dan sumber daya para ahli eksekutif di Indonesia untuk membuat sumber daya publik sistem dewan untuk asosiasi yang mahir dan menarik, seperti halnya bekerja pada sifat administrasi publik. Eksplorasi ini memiliki kemungkinan aplikasi di negara-negara pertanian lainnya. (Wahyuni, 2012), memimpin penelitian yang mengidentifikasi dampak sumber daya papan yang terdiri dari bagianbagian saham, bukti pembeda, tinjauan hukum dan penilaian sumber daya pada peningkatan pemanfaatan sumber daya tetap otoritas publik Peraturan Sumbawa Barat. Contoh dipilih menggunakan pengujian purposive. Kajian ini menggunakan 2 (dua) alat yang berwawasan, yaitu berbagai pemeriksaan kekambuhan dan Information Envelopment Examination (DEA). Hasil penyelidikan dengan menggunakan DEA menunjukkan bahwa dari 8 
Satker Perakitan Mekanikal Daerah yang ditetapkan sebagai instansi khusus teritorial yang bertujuan untuk pemenuhan upah khas daerah, hanya 3 Satuan Kerja Perangkat Daerah (SKPD) Provinsi yang ideal dalam penggunaan haknya. sumber daya sedangkan 5 Satuan Kerja Perangkat Daerah (SKPD) lainnya belum. pemanfaatan yang ideal dari sumber daya yang layak. (Antoh, 2012), pemeriksaan diarahkan pada sumber daya para eksekutif dalam rangka perampingan sumber daya tetap (tanah) pada lingkungan pemerintah dalam Peraturan Paniai. Dengan menggunakan teknik pemeriksaan purposive, jumlah tes pemeriksaan yang diambil adalah 50 responden. Faktor-faktor yang digunakan adalah stok sumber daya, tinjauan legitimasi sumber daya, penilaian sumber daya, dan pengamatan dan pengendalian sumber daya. Berdasarkan hasil penelitian dengan menggunakan alat uji Kekambuhan Langsung Berbeda, menunjukkan bahwa stok sumber daya tunggal belum terbukti memiliki dampak positif dan besar pada peningkatan sumber daya tetap (tanah) yang berarti tidak sesuai spekulasi. Tinjauan sumber daya yang sah secara eksklusif telah terbukti memiliki dampak positif dan kritis pada perampingan sumber daya tetap (tanah, secara terpisah, penilaian sumber daya belum terbukti berpengaruh positif terhadap peningkatan sumber daya tetap (tanah), pengamatan dan pengendalian sumber daya terbukti memiliki dampak positif dan besar terhadap peningkatan sumber daya tetap (tanah dan bangunan). Pengkajian secara sekaligus menunjukkan bahwa keempat faktor tersebut, khususnya stok sumberdaya, tinjauan legitimasi sumberdaya, penilaian sumberdaya dan pengamatan dan pengendalian sumberdaya mempunyai hasil yang besar/konstruktif terhadap perampingan sumberdaya tetap (tanah). Hal ini dibuktikan dengan nilai F-hitung > F - tabel. Dan selanjutnya penilaian sumber daya seperti halnya pemeriksaan dan pengendalian sumber daya terbukti memiliki hasil yang besar/konstruktif pada peningkatan sumber daya tetap (tanah). Hal ini dibuktikan dengan nilai F-hitung > F-tabel. Dan selanjutnya penilaian sumber daya seperti halnya pemeriksaan dan pengendalian sumber daya terbukti memiliki hasil yang besar/konstruktif pada peningkatan sumber daya tetap (tanah). Hal ini dibuktikan dengan nilai F-hitung > F-tabel. Terlebih lagi (Nasution, 2014), memimpin tinjauan tentang dampak sumber daya dewan terhadap peningkatan sumber daya klinik Medis Jiwa Teritorial Wilayah Sumatera Utara. Dengan menggunakan teknik purposive testing, jumlah tes pemeriksaan yang diambil adalah 40 responden. Mengingat konsekuensi dari penyelidikan yang menggunakan alat uji Kekambuhan Langsung Berbeda, ini menunjukkan bahwa tiga faktor, khususnya stok sumber daya, tinjauan hukum, dan penilaian sumber daya yang ditunjukkan memiliki dampak besar/positif pada kemajuan sumber daya klinik darurat mental lokal di DPRD Sumut.

Penelitian ini bertujuan untuk menganalisis pengaruh inventarisasi aset, legal audit aset, penilaian aset, serta pengawasan dan pengendalian aset terhadap tingkat optimalitas aset tetap (tanah) Pemerintah Provinsi Jambi. Diharapkan penelitian ini bisa memberikan masukan yang bermanfaat bagi Prov. Jambi dalam pemanfaatan asetnya.

\section{METODE}

Penelitian ini didesain untuk melihat hubungan yang signifikan antara variabel $\mathrm{X}$ terhadap variabel $\mathrm{Y}$ yaitu pengaruh manajemen aset terhadap tingkat optimalitas aset tetap khususnya tanah milik Provinsi Jambi. Pengamatan yang dilakukan dalam penelitian ini pada cakupan waktu bersifat cross section/oneshot, artinya informasi/data yang diperoleh dari penelitian ini yaitu berupa hasil pengumpulan data yang dilakukan pada satu satuan waktu tertentu. penelitian ini menggunakan Populasi pada pegawai yang bertugas mengurus aset daerah pada Pemerintah Provinsi Jambi. Sampel yang diambil ini diharapkan dapat memberikan gambaran karakter pengelolaan aset daerah yang ada di Pemerintah Provinsi Jambi.

Penelitian ini dilaksanakan di instansi OPD Pemprov Jambi. Digunalan teknik purposive sampling dalam pengambilan sampel, yang terbatas pada orangorang terte ntu yang dapat memberikan informasi penting dan memahami serta dapat memberikan gambaran sesuai tujuan pemeriksaan. Penelitian ini memiliki sampel berjumlah 46 orang yang terdiri dari Kasubbag Umum/Kasubbag Keuangan dan Aset berjumlah 23 orang \& Pengurus barang berjumlah 23 orang.

Berbagai informasi yang digunakan dalam tinjauan ini dilengkapi dengan 2 metodologi, yaitu eksplorasi perpustakaan khusus dan penelitian lapangan.

Skala likert digunakan pada Teknis alat analisis data. Menurut (Ikmal, n.d.) Pengujian instrument pada Uji reliabilitas dan Uji Validitas suatu variabel disebutkan reliable jika menunjukkan nilai Cronbach Alpha > 0,70.

Seperti yang ditunjukkan oleh (Nursalim, 2018) Pemeriksaan kekambuhan adalah penyelidikan tentang bagaimana satu variabel lingkungan dipengaruhi oleh satu/lebih faktor bebas yang sepenuhnya bertujuan untuk menilai serta mempengaruhi nilai variabel terikat yang bergantung pada nilai yang diketahui dari otonomi tersebut. variabel.

\section{Operasional Variabel}

1. Inventarisasi aset $\left(\mathrm{X}_{1}\right)$ merupakan siklus kerja yang diidentikkan dengan pengumpulan informasi, pengkodean/penamaan, pengumpulan dan pembukuan/organisasi baik secara nyata maupun sah. Misalnya dalam berbagai informasi tentang bentuk, 
wilayah, volume/jumlah, jenis, alamat sumber daya untuk situasi ini sumber daya tetap tanah.

2. Legal audit aset $\left(X_{2}\right)$ merupakan siklus kerja yang diidentifikasi dengan rencana permainan yang jelas sehubungan dengan situasi dengan tanggung jawab atas sumber daya sebagai wasiat, penggunaan, dan pemindahan sumber daya. Dimana lawful review lebih diidentikkan dengan aktivitas yang halal.

3. Penilaian aset $\left(\mathrm{X}_{3}\right)$ merupakan siklus kerja untuk menilai sumber daya yang dimiliki oleh otoritas publik, untuk situasi ini pemerintah lingkungan. yang biasanya dilakukan oleh ahli pemeriksaan gratis (konfirmasi) dengan menyatakan harga sumber daya dalam rupiah. Konsekuensi dari penilaian digunakan untuk memutuskan nilai kekayaan sumber daya.

4. Pengawasan dan pengendalian aset $\left(\mathrm{X}_{4}\right)$ adalah suatu siklus kerja yang diselesaikan dengan membina Harta Teritorial Badan Kerangka Data (SIMDA BMD). Karena pengawasan dan pengendalian dengan Kerangka Data Administrasi akan membatasi kesalahan yang dibuat dalam suatu administrasi, misalnya KKN.

\section{HASIL DAN PEMBAHASAN \\ Deskripsi Responden}

Dari 46 responden yang dipilih dicirikan ke dalam empat sudut pandang, khususnya dilihat dari jenis kelamin, ada 27 responden (64\%) laki-laki dan 21 responden $(35 \%)$ perempuan. Dari sistesis umur yang dibagi menjadi empat kelompok, terdapat 6 responden (10 $\%)$ berumur $<30$ tahun, 20 responden $(20 \%)$ berumur 31 40 tahun, 11 responden (37\%) berumur 41-50 tahun dan 10 responden $(31 \%)$. ) jatuh tempo > 51 tahun. Dari struktur pelatihan terdapat 12 responden (43\%) berpendidikan SLTA, 7 responden (29\%) berpendidikan D1/D3, 24 responden berpendidikan sertifikasi empat tahun, dan 6 responden $(27 \%)$ dengan pendidikan sarjana. Dari susunan jabatan/eselon, yang dirangkai menjadi Eselon IV ke atas 23 responden (33\%), Kabag Umum 23 responden $(50 \%)$ selain Administrator Barang sebanyak 24 responden $(58 \%)$.

\section{Uji Validitas}

Tabel 1. Hasil Perhitungan Uji Validitas

\begin{tabular}{ccccc}
\hline $\begin{array}{c}\text { No } \\
\text { Item }\end{array}$ & r Hitung & r tabel 5\% (46) & Signifikansi & Kriteria \\
\hline X1 & & & & \\
\hline X1a & 0,854 & 0,291 & 0,000 & Valid \\
\hline X1b & 0,902 & 0,291 & 0,000 & Valid \\
\hline X1c & 0,833 & 0,291 & 0,000 & Valid \\
\hline X1d & 0,742 & 0,291 & 0,000 & Valid \\
\hline X2 & & & & \\
\hline X2a & 0,707 & 0,291 & 0,000 & Valid \\
\hline X2b & 0,746 & 0,291 & 0,000 & Valid \\
\hline
\end{tabular}

\begin{tabular}{ccccc}
\hline X2c & 0,741 & 0,291 & 0,000 & Valid \\
\hline X2d & 0,855 & 0,291 & 0,000 & Valid \\
\hline X3 & & & & \\
\hline X3a & 0,716 & 0,291 & 0,000 & Valid \\
\hline X3b & 0,484 & 0,291 & 0,001 & Valid \\
\hline X3c & 0,829 & 0,291 & 0,000 & Valid \\
\hline X3d & 0,842 & 0,291 & 0,000 & Valid \\
\hline X4 & & & & \\
\hline X4a & 0,677 & 0,291 & 0,000 & Valid \\
\hline X4b & 0,794 & 0,291 & 0,000 & Valid \\
\hline X4c & 0,818 & 0,291 & 0,000 & Valid \\
\hline X & & & & \\
\hline Y1 & 0,591 & 0,291 & 0,000 & Valid \\
\hline Y2 & 0,673 & 0,291 & 0,001 & Valid \\
\hline Y3 & 0,748 & 0,291 & 0,000 & Valid \\
\hline Y4 & 0,723 & 0,291 & 0,000 & Valid \\
\hline
\end{tabular}

Sumber: Data diolah

Dengan memanfaatkan software SPSS 17.0, diketahui bahwasanya setiap pertanyaan adalah sah. Hal ini terlihat dari nilai koefisien hubungan absolut yang lebih menonjol dibandingkan nilai dasar koefisien hubungan ( $\mathrm{r}$ tabel). Dengan contoh 48 responden, nilai dasar koefisien koneksi adalah 0,291. Tabel 2. menunjukkan bahwa semua asersi dinyatakan sah, dengan alasan memiliki $r$ hitung $\geq \mathrm{r}$ tabel $(0,291)$.

\section{Uji Reabilitas}

Table 2. Hasil Uji reliabilitas yaitu sebagai berikut:

\begin{tabular}{|c|c|}
\hline Cronbach's Alpha & $\mathrm{N}$ of Items \\
\hline .851 & 4 \\
\hline
\end{tabular}

Sumber: Data diolah

Efek samping dari uji ini dalam tinjauan ini menghasilkan nilai Cronbach alpha (a) $=0,851$, yang artinya 0,851 lebih penting dari pada ukuran (Nunnaly, 1994) yaitu 0,70 (Ghozali H. I., 2012). Dengan demikian, segala hal yang digunakan dalam penjajakan di Pemprov Jambi merupakan pemungutan suara yang dapat diandalkan dan dapat dimanfaatkan.

\section{Hasil Persepsi Responden}

Tabel 3. Rekapitulasi Jawaban Responden

\begin{tabular}{ccccccc}
\hline \multirow{2}{*}{ Variabel } & \multicolumn{3}{c}{ Skala likert } & \multicolumn{1}{c}{ Total } \\
\cline { 2 - 7 } & $\mathbf{1}$ & $\mathbf{2}$ & $\mathbf{3}$ & $\mathbf{4}$ & $\mathbf{5}$ & \\
\hline Inventarisasi & 1 & 19 & 48 & 108 & 16 & 192 \\
\hline Legal audit & - & 12 & 51 & 125 & 4 & 192 \\
\hline Penilaian & - & 4 & 38 & 131 & 19 & 192 \\
\hline $\begin{array}{c}\text { Pengawasan } \\
\&\end{array}$ & - & 2 & 14 & 117 & 11 & 144 \\
$\begin{array}{c}\text { Pengendalian } \\
\text { Jumlah }\end{array}$ & $\mathbf{1}$ & $\mathbf{3 7}$ & $\mathbf{1 5 1}$ & $\mathbf{4 8 1}$ & $\mathbf{5 0}$ & $\mathbf{7 2 0}$ \\
\hline
\end{tabular}




\begin{tabular}{ccccccc}
\hline $\begin{array}{c}\text { Total (skor x } \\
\text { jumlah) }\end{array}$ & $\mathbf{1}$ & $\mathbf{7 4}$ & $\mathbf{4 5 3}$ & $\mathbf{1 9 2 4}$ & $\mathbf{2 5 0}$ & $\mathbf{2 7 0 2}$ \\
\hline$\%$ & $\mathbf{0 , 0}$ & $\mathbf{2 , 7}$ & $\mathbf{1 6 , 7 6}$ & $\mathbf{7 1 , 2 0}$ & $\mathbf{9 , 2}$ & $\mathbf{1 0 0}$ \\
\hline & $\mathbf{3}$ & $\mathbf{3}$ & $\mathbf{5}$ & \\
\hline
\end{tabular}

Sumber: Data diolah

Akibat rekap jawaban responden menunjukkan bahwa pengulangan keputusan jawaban yang paling diperhatikan dari responden ialah keputusan jawaban tepat 4 atau setuju sebesar 1.924 (71,20\%), kemudian pada saat itu disusul keputusan jawaban tiga atau tidak bias pada 453 (16,76 persen), keputusan jawaban tepat 5 atau sangat setuju 250 $(9,25 \%)$, keputusan jawaban tepat dua atau berbeda 74 $(2,73 \%) \&$ keputusan jawaban terakhir 1 ( 0,03 persen).

\section{Hasil Regresi Linear Berganda \\ Uji t (t-test)}

Tabel 4. Uji Signifikan Parameter Individual (Uji Statistik t)

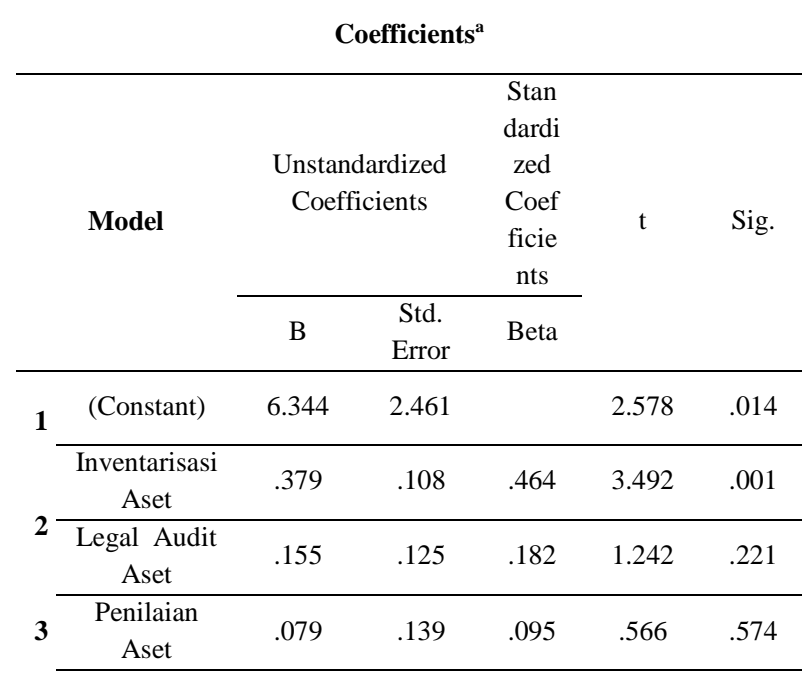

$\begin{array}{lllllll}\mathbf{4} & \begin{array}{c}\text { Pengawasan } \\ \text { dan } \\ \\ \text { Pengendalia } \\ \text { n Aset }\end{array} & .065 & .166 & .064 & .392 & .697 \\ \mathbf{5} & & & & & \end{array}$

a. Dependent Variable: Optimalisasi Aset

Sumber: Data diolah

\section{Pengujian Hipotesis Pertama $(\mathrm{H1})=\mathrm{X} 1 \rightarrow \mathrm{Y}$}

Disadari bahwa Sig insentif dampak X1 terhadap Y adalah $0,001<0,05$ dan nilai $t$ hitung sebesar 3,492>0,1954, sehingga cenderung beralasan bahwa $\mathrm{H} 1$ diakui yang menyiratkan adanya pengaruh $\mathrm{X} 1$ terhadap Y.

II. Pengujian Hipotesis Kedua $(\mathrm{H} 2)=\mathrm{X} 2 \rightarrow \mathrm{Y}$

Disadari bahwa Sig insentif pengaruh X2 terhadap Y adalah 0,221 >0,05 dan nilai t hitung 1,242<0,201954, sehingga cenderung beralasan bahwa $\mathrm{H} 2$ ditolak, artinya tidak ada pengaruh $\mathrm{X} 2$ pada $\mathrm{Y}$.

\section{III.Pengujian Hipotesis Ketiga $(\mathrm{H3})=\mathrm{X3} \rightarrow \mathrm{Y}$}

Disadari bahwa Sig insentif pengaruh X3 terhadap Y adalah 0,574>0,05 dan nilai t hitung 0,566<0,201954, sehingga cenderung beralasan bahwa $\mathrm{H} 3$ ditolak, yang berarti tidak ada pengaruh X3 terhadap Y.

\section{IV.Pengujian Hipotesis Keempat $(\mathrm{H} 4)=\mathrm{X} 4 \rightarrow \mathrm{Y}$}

Disadari bahwa Sig insentif dampak X4 terhadap Y adalah 0,697>0,05 dan nilai t hitung 0,392<0,201954, sehingga cenderung beralasan bahwa $\mathrm{H} 3$ ditolak, yang berarti tidak ada pengaruh $\mathrm{X} 4$ terhadap $\mathrm{Y}$.

\section{Uji statistik F (F-test)}

Tabel 6. Uji Signifikansi Simultan (Uji Statistik F)

\begin{tabular}{crrrrr}
\hline \multicolumn{6}{c}{ ANOVA $^{\text {a }}$} \\
\hline Model & $\begin{array}{c}\text { Sum of } \\
\text { Squares }\end{array}$ & \multicolumn{1}{c}{ df } & $\begin{array}{c}\text { Mean } \\
\text { Square }\end{array}$ & \multicolumn{1}{c}{ F } & Sig. \\
\hline Regression & 43.365 & 4 & 10.841 & 5.852 & $.001^{\mathrm{b}}$ \\
\hline Residual & 75.961 & 41 & 1.853 & & \\
\hline Total & 119.326 & 45 & & &
\end{tabular}

a. Dependent Variable: Optimalisasi Aset

Hasil Uji ANOVA (uji F) menunjukkan nilai $\mathrm{F}$ yang ditentukan sebesar 5,852 dengan kemungkinan 0,001. F tabel adalah 2,59 dengan $=5 \%$. Dengan cara ini $\mathrm{F}$ termasuk > F tabel atau dengan demikian H0 dihilangkan dan Ha mengakui, hal itu cenderung beralasan bahwa semua faktor otonom: stok sumber daya, tinjauan sah sumber daya, penilaian sumber daya, dan pengamatan dan pengendalian sumber daya secara bersamaan mempengaruhi variabel terikat, khususnya optimalitas aktiva tetap (tanah).

\section{Pembahasan Hasil Penelitian \\ Pengaruh Inventarisasi Aset terhadap tingkat optimalitas aset tetap (tanah)}

Dampak stok sumber daya pada tingkat ideal sumber daya tetap sebagai tanah. Dari hasil uji-t tabel 5. koefisien, diketahui bahwa Sig insentif untuk dampak stok (X1) terhadap optimalitas sumber daya (Y) adalah 0,001 $<0,05$ $\&$ nilai $\mathrm{t}$ hitung adalah 3,492 > 201954, sehingga cenderung dianggap bahwa stok mempengaruhi optimalitas sumber daya tetap. Hal ini juga menunjukkan bahwa pelaksanaan suatu saham termasuk pengumpulan informasi, kodifikasi/penamaan, pengumpulan, dan akuntansi/organisasi yang baik akan memberikan harapan yang layak akan tingkat ideal sumber daya tetap tanah juga.

Berdasarlkan hasil Hasil Wawancara dan Observasi memberikan hasil bahwa Inventarisasi sejauh ini telah dilaksanakan, seluruh OPD yang ada di lingkup Pemerintah Provinsi Jambi sudah memiliki Buku Inventaris termasuk mencatatkan aset tetap tanah. 
Hipotesis pertama membuktikan bahwa pada penelitian ini aset tetap terdapat pengaruh positif dan signifikan antara inventarisasi aset terhadap tingkat optimalitas (tanah)

Hasil penelitian ini selaras dengan Teori Perilaku Terencana (Theory of Planned Behavior) menurut Ajzen dimana timbulnya niat untuk berperilaku dalam (Azwar, n.d.) ditentukan oleh factor :

1. Behavioral Beliefs, adalah keyakinan seseorang pada hasil dari suatu perilaku dan penilaian pada hasil ini..

2. Normative Beliefs, adalah keyakinan sehubungan dengan asumsi yang mengatur orang lain dan inspirasi untuk memenuhi asumsi tersebut.

3. Control Beliefs, adalah keyakinan tentang adanya halhal yang membantu/menekan perilaku yang akan ditampilkan dan wawasan tentang seberapa kuat halhal yang membantu dan merusak perilaku (perceived power).

Variabel yang termasuk menentukan munculnya harapan untuk bertindak ialah Behavioral Beliefsyakni, khususnya keyakinan individu pada konsekuensi dari suatu perilaku dan penilaian hasil ini. Stok yang dalam prosesnya terdiri dari pengumpulan informasi, pengkodean, pengumpulan dan pembukuan yang tahapan kerjanya diatur oleh Permendagri Nomor 17 Tahun 2007 memberikan kepastian kepada pelaku atas keadaan ini Pengelola, Pengguna, Asisten Manajer, dan Manajemen BMD bahwa setelah tindakan stok dilakukan, itu akan membawa keuntungan bagi pemerintah lingkungan. Karena stok informasi BMD ternyata lebih bisa diandalkan dan bertanggung jawab. Hal ini terlihat dari produkproduk di lapangan setua barang dagangan yang tercatat dan tertuang dalam laporan anggaran. Selain itu, tentunya dapat memberikan akomodasi kepada pemerintah provinsi untuk memanfaatkan sumber daya yang ada, baik yang akan dimanfaatkan oleh pemerintah daerah untuk membantu tugas pokok dan kapasitas dalam menjalankan kewenangan publik dan menawarkan dukungan yang cemerlang kepada daerah, atau bisa juga sebaliknya. memanfaatkan sumber daya. dengan cara menyewakan kepada pihak luar.

(Siregar, 2004) menyatakan bahwa stok sumber daya terdiri dari dua perspektif, khususnya stok fisik dan yuridis/legal. Perspektif aktual terdiri dari bentuk, wilayah, luas, volume/jumlah, jenis, alamat, dan lain-lain. Sedangkan sudut pandang yuridis adalah situasi dengan kontrol, masalah hukum yang diklaim, seperti batas waktu untuk dominasi dan proses kerja yang dilakukan dalam stok sumber daya adalah pemilahan informasi, kodifikasi/penamaan, pengumpulan dan akuntansi/organisasi sesuai dengan tujuan organisasi. sumber daya eksekutif. Undang-undang tidak resmi Nomor 6 Tahun 2006 tentang Pengelolaan Barang Milik
Negara/Daerah menyatakan bahwa saham adalah suatu gerak untuk mengumpulkan informasi, mencatat dan melaporkan akibat dari pemilahan informasi atas kekayaan teritorial. Stok properti teritorial dilakukan oleh klien barang dagangan sampai batas tertentu sekali setiap lima (5) waktu yang lama dan hasilnya dipertanggungjawabkan kepada pengawas produk selambat-lambatnya tiga (90 hari) setelah penyelesaian stok. Stock dilakukan untuk mencatat sumber daya terdekat untuk pencatatan tambahan dari sumber daya tersebut yang kemudian dirinci untuk alasan penyusunan Laporan BMD, dimana laporan tersebut akan menjadi penting untuk Laporan Keuangan Pemda. Selain itu, laporan efek samping saham juga memungkinkan pemerintah daerah untuk memiliki informasi tentang sumber daya yang dapat digunakan untuk membantu tugas dan kapasitas utama mereka dalam melayani daerah dan juga dapat digunakan untuk disewakan ke berbagai pertemuan (lebih lanjut untuk digunakan) untuk meningkatkan gaji provinsi.

(Yusuf, 2013) menyatakan bahwa pencatatan keuangan daerah yang penting bagi laporan keuangan akan selesai dan kokoh jika organisasi sumber daya antara sumber daya aktual, arsip kepemilikan, dan organisasi dalam buku stok memiliki kesesuaian. Dengan aliran manajerial yang disengaja, tingkat kepercayaan dalam interaksi regulasi akan secara konsisten dipercaya oleh setiap individu yang membaca dengan teliti laporan anggaran. Selain itu (Yusuf, 2013) menyatakan bahwa pelaksanaan organisasi diselesaikan oleh petugas keuangan produk dan pusat pendaftaran atau otoritas yang didelegasikan untuk mengawasi sumber daya/BMD. Pencatatan dilakukan untuk memberikan jaminan pencatatan terhadap setiap barang yang dibeli atau berubah kondisi karena perubahan atau karena pemusnahan, dan sebagai alasan untuk memberikan data kepada pihak yang membutuhkan dalam rangka melaksanakan tanggung jawab atas sumber daya para pengurus/BMD secara langsung. jalan. Salah satu perkumpulan yang membutuhkan data tentang sumber daya tersebut adalah individu yang perlu memanfaatkan sumber daya BMD, baik melalui menyewa, memperoleh, memanfaatkan partisipasi, bekerja untuk serah terima atau bekerja untuk serah terima.

Penelitian tentang pengaruh inventarisasi terhadap optimalisasi aset pernah dilaksanakan oleh (Nursalim, 2018) pada Pemerintah Kota Baubau yang menunjukan hasik bahwa inventarisasi berpengaruh positif dan signifikan terhadap optimalitas aset tetap (tanah dan bangunan), (Nasution, 2014) pada RSJ SUMUT dengan hasil penelitian inventarisasi berpengaruh positif dan signifikan terhadap optimalisasi aset. Penelitian ini menyarankan supaya pihak RS harus melakukan pengadaan alat kesehatan yang baru untuk menggantikan 
peralatan yang sudah rusak supaya bisa dipergunakan sesuai dengan kebutuhannya. Seterusnya Sri Fazatin (2013) pada penelitiannya pada pemda Jepara yang menunjukkan bahwa inventarisasi aset berpengaruh positif dan signifikan terhadap optimalisasi pemanfaatan aset, dan (Simunapendi, 2015) pada Pemda Kab. Waropen dengan hasil inventarisasi juga memiliki pengaruh positif dan signifikan terhadap pemanfaatan aset tetap. Dan penelitian lainnya juga dilakukan oleh (MURKANA, 1999), yang mengkaji terkait manajemen inventarisasi barang daerah di DKI Jakarta. Manajemen inventarisasi barangg daerah dimaksudkan untuk memberikan data yang lengkap, valid dan mutakhir dalam bentuk daftar inventaris barang daerah untuk menunjang kelancaran \& kemudahan dalam pemanfaatan \& pengelolaannya oleh Pemerintah.

\section{Pengaruh Legal Adit terhadap tingkat optimalitas aset tetap (tanah)}

Dampak tinjauan yang sah pada tingkat ideal sumber daya tetap lahan. Dari hasil uji t tabel 5. Disadari bahwa Sig Insentif untuk Pengaruh Peninjauan Kembali (X2) terhadap Y adalah 0,221>0,05 dan nilai t adalah 1,242 < 0,201954, sehingga cenderung disimpulkan bahwa Peninjauan Kembali tidak berpengaruh terhadap derajat ideal. sumber daya tetap lahan (Y).

Teori Implementasi Kebijakan menurut Grindle tidak sejalan dengan hasil pengujian ini, dimana keberhasilan implementasi dipengaruhi oleh isi kebijakan yang mencakup beberapa hal sebagai berikut:

1. Kepentingan yang terpengaruhi oleh kebijakan

2. Jenis manfaat yang dihasilkan

3. Derajat perubahan yang diinginkan

4. Kedudukan pembuat kebijakan

5. Siapa pelaksana program

6. Sumber daya yang dikerahkan

Salah satu substansi pendekatan yang dimaksud adalah tingkat kemajuan yang diinginkan. Motivasi di balik tingkat kemajuan yang ideal adalah bahwa dengan adanya tinjauan yang sah, pemerintah lingkungan membutuhkan perbedaan pandangan dan pemahaman tentang pentingnya bukti dan catatan kepemilikan untuk membantu perlindungan penggunaan dan penggunaan sumber daya di pemerintah terdekat. Norma untuk sumber daya tanah adalah bahwa mereka harus memiliki status kepemilikan sebagai otentikasi, untuk sumber daya kendaraan mekanik mereka harus memiliki verifikasi kepemilikan sebagai bukti tanggung jawab untuk kendaraan (BPKB), dan untuk struktur dan struktur yang dilengkapi dengan Izin Bangunan (IMB).

Disamping itu juga pelaksanaan untuk legal audit juga berujung pada kepastian hukum. Menurut UNDP hasil penelitian ini juga tidak sejalan dengan teori Good Governance. Beberapa karakteristik pelaksanaan good governance, sbb:

1. Participation

2. Rule of Law

3. Transparency

4. Responsiveness

5. Consensus Orientation

6. Equity

7. Efficiency and Effectiveness

8. Accountability

Salah satu standar administrasi yang baik adalah kepastian hukum. Dengan sumber daya yang sah, memiliki status kepemilikan yang jelas secara langsung memberikan kepastian hukum terhadap sumber daya tersebut. Hal ini sangat penting untuk menghindari perdebatan dan perampasan dari pihak-pihak yang tidak dapat diandalkan dan perlu menguasai sumber daya pemerintah lingkungan. Permendagri No. 17/2007 menyatakan bahwa direksi, klien atau calon perantara klien berkomitmen untuk membela BMD di bawah pengaruh mereka. Salah satu jenis keamanan yang dimaksud adalah keamanan yang sah, yang menggabungkan latihan untuk menyelesaikan bukti status kepemilikan. Konsekuensi dari tinjauan yang menyatakan bahwa tinjauan hukum tidak berdampak pada peningkatan penggunaan sumber daya tidak sesuai dengan Permendagri Nomor 17 Tahun 2007 yang menyatakan bahwa BMD yang sangat dipengaruhi oleh legislatif terdekat harus memiliki konfirmasi status kepemilikan untuk dilindungi secara sah, seperti di dalamnya tidak mempertimbangkan kejang atau pertanyaan dengan pihak lain. Karena BMD dengan status dan konfirmasi kepemilikan yang jelas akan membuka peluang penggunaan yang lebih ideal untuk disewakan atau usaha bersama dengan pihak luar.

Menurut (Siregar, 2004) Legal audit adalah sumber daya sejauh mana eksekutif bekerja sebagai stok status kontrol sumber daya, kerangka kerja kontrol dan sistem untuk pemindahan sumber daya, bukti yang dapat dikenali dan jawaban pengamatan untuk masalah dan prosedur yang sah untuk menangani berbagai masalah sah yang diidentifikasi dengan kontrol atau pemindahan sumber daya. Isu-isu sah yang sering dialami antara lain status lemahnya kebebasan bertempat tinggal, sumber daya yang dibatasi oleh pertemuan yang berbeda, perpindahan sumber daya yang tidak terpantau, dan lain-lain. Pada umumnya, sumber daya di lokal sebenarnya tidak menyukai status dan verifikasi kepemilikan mereka. Tidak jarang hal ini membuat sumber daya keluar dari tangan negara tetangga. Untuk situasi ini, pemerintah daerah harus mengenali dan memantau langsung kemungkinan hasil yang akan muncul jika sumber daya teritorial tidak 
disertai dengan bukti kepemilikan yang jelas. Sumber daya dengan status kepemilikan yang wajar harus memberikan keyakinan bahwa semuanya baik-baik saja pada saat penggunaan dan penggunaan. Bagaimanapun, dalam ulasan ini, ulasan yang sah tidak mempengaruhi peningkatan penggunaan sumber daya, karena banyak responden memahami bahwa sumber daya yang layak dapat digunakan dan digunakan meskipun mereka terancam dirampas oleh kelompok lain karena mereka tidak memiliki bukti kepemilikan yang jelas dan sah.

Tinjauan dengan berbagai hasil dipimpin oleh (Wahyuni, 2012) dengan judul "Pengaruh Sumber Daya Para Pelaksana Terhadap Peningkatan Penggunaan Sumber Daya Tetap dalam Kewenangan Publik Rezim Sumbawa Barat", dimana hasil eksplorasinya mengungkapkan bahwa tinjauan yang sah secara positif mempengaruhi peningkatan pemanfaatan sumber daya tetap. Sedangkan pemeriksaan dengan hasil serupa datang dari (Jamaludin, 2019) di Pemerintah Bersama Nusa Tenggara Barat (NTB) dengan efek samping dari penelitian tinjauan yang sah tidak mempengaruhi peningkatan administrasi dan penggunaan sumber daya tetap (tanah dan bangunan). Hasil investigasi dari Information Envelopment Examination (DEA) menunjukkan bahwa dari 17 SKPD yang ditetapkan sebagai instansi khusus provinsi yang bertujuan untuk mencapai pendapatan lingkungan, hanya ada 6 SKPD yang efektif dalam mengawasi dan menggunakan sumber daya tetap (tanah dan bangunan dengan nilai produktif relatif 100\%, juga (BLES, 2015) di Pemerintah Daerah Jayapura dengan konsekuensi penelitian legal review tidak mempengaruhi peningkatan sumber daya tetap (tanah dan bangunan).

\section{Pengaruh Penilaian terhadap tingkat optimalitas aset tetap (tanah)}

Dampak penilaian sumber daya pada tingkat ideal sumber daya tetap lahan. Dari hasil uji-t tabel 5.. Disadari bahwa Sig insentif untuk dampak penilaian sumber daya (X3) pada tingkat ideal sumber daya tetap seperti tanah (Y) adalah 0,574 > 0,05 dan harga $t$ adalah 0,566 < 0,201954, sehingga cenderung beralasan bahwa pergerakan valuasi tidak berdampak pada upaya untuk memperluas optimalitas sumber daya. tetap tanah di Pemerintah Bersama Jambi.

Berdasarlkan hasil Hasil Wawancara dan Observasi memberikan hasil bahwa Penilaian terhadap aset tetap tanah milik Pemerintah Provinsi Jambi belum dilakukan secara berkala. Penilaian hanya pernah dilakukan oleh Kantor Pelayanan Kekayaan Negara dan Lelang (KPKNL) sebagai penilai aset pemerintah pusat. Untuk menilai aset-aset daerah hanya dilakukan terhadap aset untuk tujuan-tujuan tertentu, misalnya untuk tujuan pemindahtanganan berupa lelang, pemusanahan, atau hibah. Dalam siklus evaluasi, dukungan dari berbagai perkumpulan juga diperlukan, khususnya penilai gratis. Hal ini sesuai dengan hipotesis Grindle tentang eksekusi strategi, di mana pencapaian eksekusi dipengaruhi oleh substansi pendekatan. Substansi pendekatan mencakup hal-hal berikut:

1. Kepentingan yang dipengaruhi oleh pendekatan

2. Macam-macam keuntungan yang tercipta

3. Tingkat kemajuan yang diinginkan

4. Posisi pembuat strategi

5. Siapa yang melaksanakan program

6. Harta yang diserahkan

Salah satu komponen substansi strategi adalah aset yang disampaikan. Dukungan dari penilai gratis karena kemampuan mereka digunakan saat mengevaluasi sumber daya membawa keuntungan pada daya dukung sumber daya ini. Saat ini di lingkungan pemerintahan yang dikelola negara terdapat banyak sumber daya yang tidak memiliki harga diri sehingga metode yang terlibat dalam penggunaan dan penggunaannya tidak berjalan dengan baik, sehingga sangat penting untuk mensurvei sumber daya yang dilengkapi oleh penilai yang memiliki keahlian di bidangnya. valuasi, sehingga sumber daya yang saat ini tidak bernilai dapat memiliki harga diri dan dapat dimanfaatkan atau digunakan segera. Penilaian menurut (Hidayanti \& Harjanto, 2015) adalah suatu perencanaan/penilaian atas nilai suatu kepentingan atas suatu properti/properti karena alasan tertentu. Sementara itu, sesuai dengan Pedoman Penggembalaan Rumah Tangga Nomor 17 Tahun 2007 tentang Ketentuan Khusus Penatausahaan Barang Milik Daerah, penilaian barang milik daerah dilengkapi dengan penyiapan catatan keuangan pemerintah daerah, penggunaan dan pemindahan wilayah. properti. Penilaian properti lokal diselesaikan oleh kelompok yang ditunjuk oleh Kepala Wilayah dan dapat mencakup penilai otonom yang dijamin di area pemeriksaan sumber daya.

Salah satu alasan evaluasi adalah untuk memanfaatkan sumber daya. Untuk situasi ini, sumber daya yang digunakan (disewakan) kepada pihak luar pada awalnya harus memiliki nilai yang wajar dan wajar, sehingga selama waktu yang dihabiskan untuk menyewa, nilai yang akan diperoleh dapat sesuai dengan penggunaan yang diberikan oleh sumber daya tersebut. Sumber daya yang digunakan melalui penyewaan atau sebagai tim dengan pertemuan yang berbeda akan memperoleh pendapatan untuk daerah tersebut. Dukungan dari penilai otonom sebagai kemampuan mereka digunakan saat mengevaluasi sumber daya untuk hasil pemeriksaan diandalkan untuk memberikan hasil yang bertanggung jawab dan langsung. Hal ini sesuai dengan hipotesis Good Governanace dari 
UNDP, dimana aturan yang harus dipenuhi untuk membuat administrasi yang hebat adalah lugas dan bertanggung jawab. Siregar (2016:107) menyatakan bahwa salah satu unsur yang membuat sumber daya atau aset atau potensi provinsi belum terawasi dan dimanfaatkan secara ideal adalah masalah penilaian yang salah. Memang, bisa dikatakan bahwa ada lebih banyak sumber daya lokal yang membuat orang miskin tergerak oleh penilaian. Memang, dampak dari penilaian ini akan dimanfaatkan sebagai alasan untuk bekerja pada penatausahaan sumber daya provinsi agar dapat digunakan secara ideal. Hipotesis ini sesuai dengan konsekuensi eksplorasi yang menyatakan bahwa evaluasi mempengaruhi perampingan penggunaan sumber daya.

Penelitian Emma (AYOMI, 2014) dengan judul "Pengaruh Manajemen Aset terhadap Optimalisasi Aset Tetap (Tanah dan Bangunan) Pemda Kab. Manokwari" mendukung penelitian ini dengan hasil penilaian tidak terbukti memiliki pengaruh yang signifikan terhadap optimalisasi aset tetap (tanah dan bangunan).

\section{Pengaruh Pengawasan \& Pengendalian terhadap tingkat optimalitas aset tetap (tanah)}

Pengaruh ini pada tingkat ideal sumber daya tetap lahan. Dari hasil uji t-tabel diketahui bahwa nilai Sig insentif untuk dampak pengelolaan dan pengendalian sumber daya (X4) fair and square of resource optimality (Y) adalah 0,697>0,05 dan nilai t-hitung sebesar 0,392 $<0,201954$, sehingga sangat mungkin diduga bahwa pengawasan dan pengendalian sumber daya tidak berpengaruh pada derajat ideal sumber daya tetap lahan (Y). Status keberadaan sumber daya adalah salah satu ukuran untuk memutuskan pameran sumber daya. Sumber daya harus digunakan dengan aman dan berhasil. Ini menyiratkan bahwa sumber daya harus dijaga dalam kondisi yang memuaskan untuk penggunaan yang diharapkan dan memenuhi pedoman kesejahteraan dan keamanan yang terkait. Dengan asumsi sumber daya tidak mengalami masalah, maka, pada saat itu, kapasitas sumber daya untuk menawarkan jenis bantuan akan sesuai dengan norma yang diperlukan. Sumber daya dapat digunakan dan digunakan dengan baik jika dalam kondisi baik. Sumber daya pemerintah lingkungan yang akan sering diabaikan mengingat fakta bahwa mereka pada awalnya sangat dirugikan harus ditangani segera sehingga sumber daya dapat digunakan kembali. Ini selaras dengan Good Governance theory menurut UNDP yang menyatakan karakteristik dari Good Governance yaitu:

1. Participation

2. Rule of Law

3. Transparency

4. Responsiveness

5. Consensus Orientation
6. Equity

7. Efficiency and Effectiveness

8. Accountability

Karakteristik dari Good Governance salah satunya yaitu efektif dan efesien. Pada penggunaan dan pemanfaatannya aset harus bisa dikatakan efektif dan efisien. Dan aktiva akan memenuhinya bila kondisi fisiknya dalam keadaan yang baik, sehingga bisa digunakan optimal. Modul Prinsip dan Teknik Manajemen Kekayaan Negara Departemen Keuangan Republik Indonesia (2007) menyatakan bahwa terdapat beberapa ukuran yang dimanfaatkan dalam menentukan kinerja aset, yaitu:

1. Keadaan fisik aset

2. Kegunaan aset

3. Fungsionalisasi aset

4. Kinerja Keuangan aset

Salah satu ukuran untuk memutuskan eksekusi sumber daya adalah keadaan sumber daya. Sebuah sumber daya harus memiliki pilihan untuk digunakan secara aman dan layak, yang berarti bahwa sumber daya tersebut harus dijaga agar berada dalam kondisi yang cukup untuk digunakan untuk alasan yang diharapkan dan memenuhi prinsip-prinsip kesejahteraan dan kesejahteraan yang penting. Kapasitas sumber daya untuk menawarkan jenis bantuan akan sesuai dengan norma yang diperlukan dengan asumsi sumber daya tidak mengalami masalah. Hipotesis di atas sesuai dengan efek samping eksplorasi yang menyatakan bahwa kondisi sumber daya mempengaruhi peningkatan penggunaan sumber daya.

Tinjauan ini tidak sejalan dengan yang dilakukan oleh (Handayani, 2007) dengan judul "Faktor-faktor yang Mempengaruhi Pemanfaatan Aset Tanah dan Bangunan Gelanggang Remaja Kota madya Jakarta Pusat". Penilitian ini menyatakan bahwa keadaan aset terbukti mempunyai pengaruh terhadap pemanfaatan gelanggang remaja Kota madya Jakarta Pusat. Penelitian lainnya juga dilakukan oleh (Ouertani et al., 2008) yang menyatakan bahwa dalam mengembangkan data sumber daya yang sukses, metodologi eksekutif harus berfokus pada penanganan berbagai data yang diidentifikasi dengan sumber daya. Motivasi di balik data sumber daya papan sebenarnya adalah untuk memberikan data yang nyaman, tepat, lengkap dan stabil sehubungan dengan area dan keadaan sumber daya untuk menghasilkan navigasi yang lebih baik.

\section{Implikasi}

Implikasi toritis pada Penelitian ini diharapkan dapat menambah pengetahuan mengenai pengaruh manajemen aset terhadap optimalitas aset tetap. Pengelolaan Aset. Dalam penelitian ini walaupun hanya satu variabel memiliki pengaruh terhadap peningkatan aset tetap berupa 
tanah .Selain itu, harapan peneliti dengan dibuatnya penelitian ini dapat menambah pengetahuan mengenai manfaat pengelolaan aset untuk menambah PAD atau pemanfaatan aset provinsi jambi., sedangkan implikasi secara praktis diharapkan penelitian ini digunakan sebagai masukan pada Pemda Provinsi Jambi untuk membenahi SOP pengelolaan aset-aset milik pemerintahan.

\section{SIMPULAN}

Mengingat konsekuensi dari pemeriksaan dan percakapan eksplorasi tentang dampak sumber daya, para eksekutif pada tingkat ideal sumber daya tetap sebagai tanah di Pemprov Jambi yang menggabungkan stok sumber daya, tinjauan sah sumber daya, penilaian sumber daya dan pemeriksaan dan kontrol sumber daya, cenderung disimpulkan bahwa. Secara sendiri-sendiri variabel-variabel independent seperti tergambar dari uji t, ternyata inventarisasi, legal audit, penilaian serta pengawasan \& pengendalian aset yang menjadi unsur dalam manajemen aset tidak secara signifikan mempengaruhi tingkat optimalitas aktiva tetap berupa tanah. Dilihat dari penanganan informasi atas tanggapan yang tepat yang dilakukan oleh responden, ternyata hanya stok dasar saja yang berpengaruh signifikan terhadap peningkatan sumber daya tetap darat di Pemerintah Provinsi Jambi. Selain itu, faktor stok, tinjauan hukum, evaluasi dan pengawasan serta pengendalian sumber daya pada saat yang sama pada dasarnya berdampak pada peningkatan sumber daya tetap sebagai tanah di lingkungan Pemerintah Provinsi Jambi.

\section{REFERENCES}

Akbar, R., \& Lukman, A. (2010). Manajemen Taman Milik Pemerintah Kota Bandung Berbasiskan Pendekatan Manajemen Aset. Jurnal Teknik Sipil ITB, 17(3), 171-180.

Antoh, A. E. (2012). Manajemen Aset Dalam Rangka Optimalisasi Aset Tetap (Tanah dan Bangunan) Pemerintah Daerah (Studi di Kabupaten Paniai). Universitas Gadjah Mada.

AYOMI, E. S. (2014). Pengaruh Manajemen Aset terhadap Optimalisasi Aset Tetap (Tanah dan Bangunan) Pemerintah Daerah (Studi di Kabupaten Manokwari). Universitas Gadjah Mada.

Azwar, S. (n.d.). Sikap Manusia Teori dan Pengukurannya. 2013. Yogyakarta: Pustaka Pelajar.

BLES, E. B. (2015). Analisis Faktor-Faktor Yang Mempengaruhi Pengelolaan Aset Tetap (Tanah Dan Bangunan): Studi Pada Pemerintah Daerah Kota
Jayapura. Universitas Gadjah Mada.

Ghozali H. I. (2012). Aplikasi Analisis Multivariate dengan Program IBM SPSS 20. Badan Penerbit Universitas Diponegoro.

Handayani, Y. L. (2007). Faktor-faktor Yang Mempengaruhi Pemanfaatan Aset Tanah Dan Bangunan Gelanggang Remaja Kotamadya Jakarta Pusat. Universitas Indonesia: Tesis.

Hanis, M. H., Trigunarsyah, B., \& Susilawati, C. (2011). The application of public asset management in Indonesian local government: A case study in South Sulawesi province. Journal of Corporate Real Estate.

Hartanto, N. (2019). Implementasi PP. No. 27 Tahun 2014 Tentang Pengelolaan Barang Milik Negara/Daerah Dalam Upaya Meningkatkan Efektivitas Pengelolaan Barang dan Jasa. Journal of Management Review, 2(3), 223-237.

Hidayanti, W., \& Harjanto, B. (2015). Konsep Dasar Penilaian Properti Edisi Kedua. BPFE Universitas Gadjah Mada: Yogyakarta.

Ikmal, A. (n.d.). Analisis Pengaruh Struktur Corporate Governance dan Karakteristik Perusahaan terhadap Pengungkapan Corporate Social Responsibility di dalam Sustainability Report (Studi Eempiris pada Perusahaan Bumn Non Keuangan yang Terdaftar di Bei Periode 2012-2014). Bakrie University.

Jamaludin, J. (2019). ANALISIS EFISIENSI RELATIF TERHADAP PEMANFAATAN ASET TETAP DENGAN MENGGUNAKAN DATA ENVELOPMENT ANALYSIS (STUDI PADA PEMERINTAH DAERAH PROVINSI NTB). Jurnal SEKURITAS (Saham, Ekonomi, Keuangan Dan Investasi), 2(2), 33-59.

MURKANA, H. S. (1999). Manajemen inventarisasi barang daerah:: Studi kasus: pengelolaan/inventarisasi aset (barang) milik/dikuasai pemerintah Daerah Khusus Ibukota Jakarta. Universitas Gadjah Mada.

Nasution, E. (2014). Pengaruh Manajemen Aset Terhadap Optimalisasi Aset Rumah Sakit Jiwa Daerah Provinsi Sumatera Utara.

Nursalim, J. (2018). Pengaruh Manajemen Aset Terhadap Tingkat Optimalitas Aset Tetap (Tanah dan Bangunan) Pemerintah Kabupaten Sorong. EQUILIBRIUM: Jurnal Ilmiah Ekonomi Dan Pembelajarannya, 6(2), 139. https://doi.org/10.25273/equilibrium.v6i2.2933

Ouertani, M.-Z., Parlikad, A. K., \& McFarlane, D. C. 
(2008). Towards an approach to Select an Asset Information Management Strategy. Int. J. Comput. Sci. Appl., 5(3b), 25-44.

Phelps, A. J. (2009). An examination of the Relationship between rationale, Practice and Outcomes in Municipal Property Asset Management-A Comparative Study of the UK and Russia. University of Birmingham.

RUSTAM, R., Rafidah, R., \& Orinaldi, M. (2021). ANALISIS PENDAPATAN ASLI DAERAH (PAD) TERHADAP BELANJA PEMERINTAH PROVINSI $J A M B I$. UIN Sulthan Thaha Saifuddin Jambi.

Simunapendi, Y. (2015). PENGARUH FAKTORFAKTOR MANAJEMEN ASET TETAP TERHADAP PEMAANFATAN (TANAH DAN BANGUNAN) PEMERINTAH DAERAH (Studi kasus Kantor Bupati Kabupaten Waropen). Universitas Gadjah Mada.

Siregar, D. D. (2004). Manajemen aset: strategi penataan konsep pembangunan berkelanjutan secara nasional dalam konteks kepala daerah sebagai CEOs pada era globalisasi \& otonomi daerah. Language, 43(836p), $26 \mathrm{~cm}$.

SPI. (2007). Standar Penilai Indonesia.

Wahyuni, A. (2012). Pengaruh Manajemen Aset Terhadap Optimalisasi Pemanfaatan Aset Tetap pemerintah Kabupaten Sumbawa Barat. Universitas Gadjah Mada.

Yusuf, M. (2013). 8 Langkah Pengelolaan Aset Daerah. Salemba Empat. 